MU Libraries

mut0377specs

University of Missouri--Columbia

Digitization Information Page

Local identifier

mut 0377

Capture information

Date captured

$02 / 2013$

Scanner manufacturer

Zeutschel

Scanner model

OS 15000

Scanning system software

Omniscan V.12.4 SR4 (1947) 64-bit

Optical resolution

Color settings

File types

600 dpi

24 bit color

tiff

Source information

Source type

text book

Source ID

103334905006

Notes

Derivatives - Access copy
Compression
Editing software
Editing characteristics
Resolution
Color
File types
Notes

Tiff:compression: 1

Adobe Photoshop CS5

Contrast boosted

300

gray scale

pdf / tiff

blank pages removed for pdf 
UM Libraries Depository

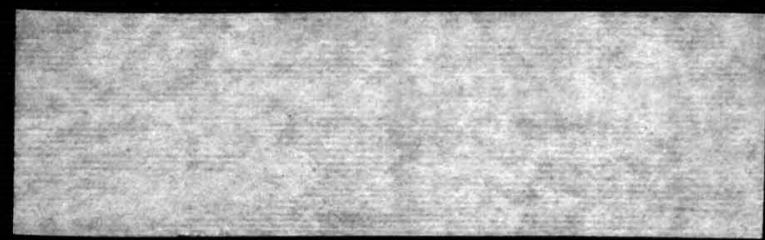




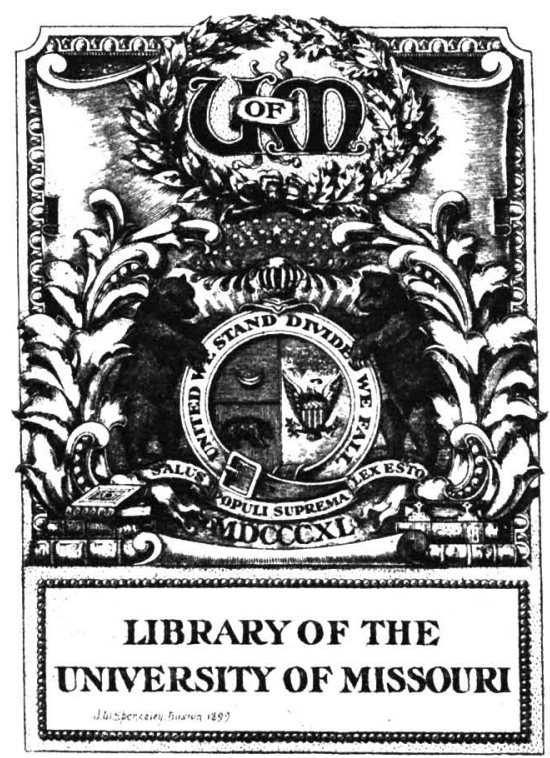

This Thesis Has Been

MICROFILMED

Negative No. T.

208

Form 26 
- AN ANATOMICAI ANAIYSIS OF THE EFFECTS OF ETHER ANESTHESIA ON THE NERVE CEIL

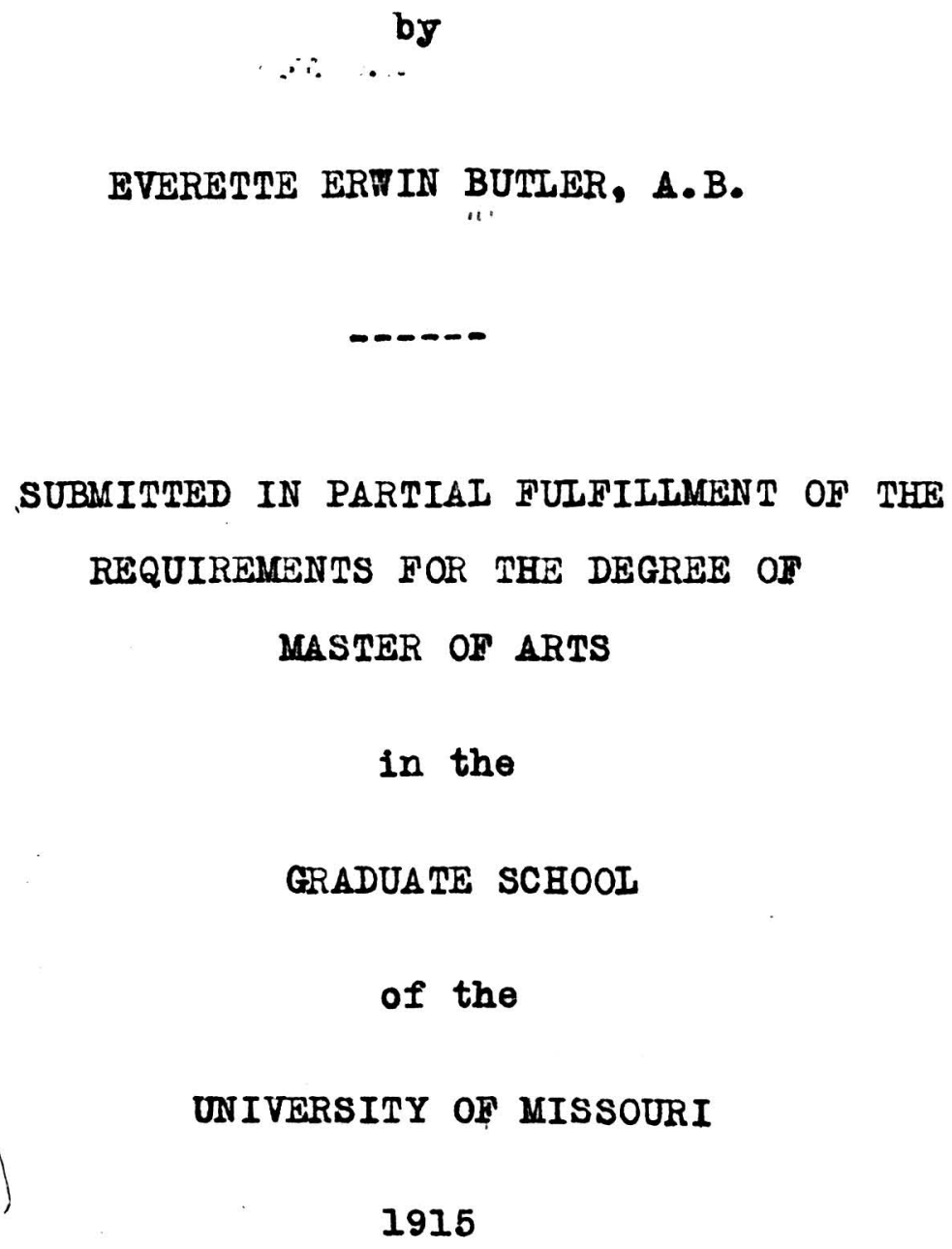


From the

\section{ILABORATORY OF PATHOLOGY \\ of the}

UNIVERSITY OF MISSOURI 


\section{$\underline{\mathrm{C}} \underline{\mathrm{N}} \underline{\underline{N}} \underline{\underline{\mathrm{E}}} \underline{\underline{N}} \underline{\underline{T}} \underline{\mathrm{S}}$}

Introduction.

Review of the Anatomical Changes in the Nerve Cell

Which are Produced by Functional Activity and

by Functional Depression.

Methods of Anesthesia Employed.

Ether Warming Apparatus and its Value in Anesthesia.

Wicroscopic Technic.

Experimental Data.

Description of the Changes Produced by Ether and Their Correlation With Depression.

Discussion of Certain Constitutional Effects of the Anesthetics.

Review of the Iiterature.

Summary.

Bibliography.

Drawings. 


\section{INTRODUCTION}

Stimuli aro either excitant or depressant. It 18 pointed out by Verworn, to quote from his General Physiology, that "the same stimuli which with olight intensity or short duration produce excitation, with increased intensity or long duration can produce entirely the opposite effect, namely, depression." As a well known example he cites morphine, heat etimulation, and the anesthetics, although it hes been shown that their essential effeot is depression. A considerable amount of orifinal experimental research has been carried on in this laboratory during the last five years on the changes in the nerve cells resulting from many forms and kinds of otimulation, both normal. and abnormal oxoltant and depreseant. The ohanges in the nerve cell produced by morphine and heat otimulation as well as other depreseants have already been studied in this laboratory but no experiments have been made up to this time as regards the effects of the anesthetios. The experiments on morphine and heat stimulation proved thet the statement of Verworn was correct as regards nerve cells. It would also be expected from the physiologioal action of the anesthetice that they would act in a oimilar way. 
In this investigation the writer has attempted to ascertain whether or not the anatomical changes producod by ether are similar to those produced by morphine and heat stimulation, namely elight excitation follored by depression.

The present experimentel work has been devoted to the anatomical changes produced in the Purkinje oell, a most highly differentiated type of nerve cell. It is this type of nerve cell upon which most of the previous work in this laboratory has been done as it is the most suitable of nerve oells for generel study. However, the lower primitive cell of spinal or aympathetic ganglia goes through the same sequence of changes as the higher and more differentiated cell of the cerebellum (Dolley, 1912). The only difference is that the higher cell is more easily and quiokly exhausted. Therefore, deductions from any single nerve cell may be applied to all nerve celle. 
A REVIEW OF THE ANATOMICAI CHANGES

IN THE NERVE CELI WHICH ARE PRODUCED BY FUNCTIONAL ACTIVITY AND BY FUNCTIONAL DEPRESSION.

The two possibilities, activity and depression, are the only functional possibilities of the nerve cell. The cell does one of two things--it does work or it is inhibited from doing work.

There have been demonstrated certain definite anatomical changes produced in the nerve cell which correspond to these physiological conditions of the cell. It is nocessary at this time to review the changes which occur during these conditions. This is done because of the fact that the correlation of the anatomical changes with physiological states of function is of recent origin and it is this interpretation of the changes which is used in the material examined by the writer.

It is necessarily important to review the anatomical changes due to functional activity before a clear conception of the changes due to depression can be obtained and for this reason they will be first considered.

The process of activity leading to exhaustion of the nerve cell has been analyzed from the evidence of a number of investigators (Hodge,1892; Guerrin1,1899; Holmgren,1900; Iugaro,1895; Mann,1895; and Vas,1892). The work of Dolley (1909) established a sequence of stages and showed that 
there is no break in the continuity of the process, and that the structural evidences of transition from stage to stage and the orderly shifts in the chromatin distribution of the cell, from an excessive amount to a very lessened amount, are distinct and definite.

It does not come within the scope of the present work to discuss the extent and nature of this evidence. The present discussion reletes mainly to morphology, with a brief reference to the biological theories which were the working hypotheses for an interpretation.

The present classificetion, which divides the process into thirteen stages, is based fundamentally on the shifts of chromatin in the cell and on the size changes of the cell. Briefly stated, in terms of the chromatin distribution, the thirteen stages are as follows (Dolley,1910) (Figures I to 13, pages 44 and 45 .

1. The resting cell. It is lacking in intranuclear chromatin except within the karyosome (nucleolus) and the amount of extranuclear chromatin varies with the individual.

2. The stage of progressive hyperchromatin, in which, in the pure type, the initial enlargement of the whole cell reaches its maximum.

3. The stage of maximum hyperchromatism, which is associated with the beginning of shrinkege.

4 and 5. The stages of regressive hyperchromatism together with the maximum of shrinkage. Coincident in 
place but separated originally to denote the differences in shape, Stage 4 being more attenuated ana spindle. Both Stages 4 and 5 are to be further divided into an early, the pure Hodge type, and a late division, characterized by the sharp beginning of the nuclear edema.

6. The return of the cytoplasmic chromatin in its continued reduction to the average normal level. This stage is principally distinguished morphologically by the maximum disproportion in the size of the nucleus oring to its much greater edema.

7 and 8. The intermediate stages leading to the primary disappearance of the cytoplasmic chromatin.

9 and 10. The stages of secondary restoration of cytoplasmic chromatin. The chromatin is first piled about the nuclear membrane and then passes out.

11. The stage of secondary disappearance of cytoplasmic chromatin. With the complete using up of the. previous supply, the karyosome is left containing the only vestige of basic chromatin in a much more exhausted looking cell.

12. The disintegration and passing out of the ultimate content contained within the karyosome.

13. The exhausted cell.

The interpretation of these stages has been made in terms of Hertwig's nucleus-plasme relation theory and his theory as to the origin of the chromatin, which is closely dependant (1903). This nucleus-plasme theory of Hertwig's, 
briefly stated, is that for every cell there is a certain definite size relation between the nuclear mass and the cell mass. So far as this relation is affected by function there are metabolic increases or decreases in the size of both - lements. He explains chromatin formation specifically in terms of this theory as based on a mutual interchange of materials. This conception, as applied to the nerve cell, is that the so-called Nissl substance, that is, extranuclear chromatin, is obtained through the activity of the nucleus.

First the cytoplasm must absorb certain materials from its surroundinge, the blood and lymph, and prepare this material for the nucleus. From the cytoplasm the material is taken into the nucleus, where it is synthesized into chromatin, or chromatin jielding substance. This chromatin substance is then resorbed by the oytoplasm and is thus stored for quick use by the cell during activity. This extranuclear chromatin is then a chromidial apparatus in the sense of R. Goldschmidt (1904), an extranuclear functioning nuclear material. Taking this as a basis, the whole process may be simply separated into three main divisions. First, the stage of hyperchromatiom is a result of the stimulus to work. The fact that the process of metabolism is slower than the cell demands under continuous stimulation causes the hyperchromatism to become less marked. The second division is the attempt of the nucleus 
to compensate and to supply the cytoplasm with further material. This necessitates a relinquishing of some of the reserve material of the nucleus, which while it serves to supply temporarily demend for more chromatin, eventually drains the nucleus. After this second supply of chromatin is used up, the nucleus makes its third attempt to furnish material by giving the chromatin stored in the karyosome. This is the last attempt of the nucleus to furnish material. When this last supply is gone the cell is left in a state of exhaustion. Such a condition is marked by a dechromatinized nucleus and plasma. Further function is inconceivable. In accordance with Hertwig's nucleus-plasma theory, the progressive enlargement of the cell in the stages of hypochromatism is necessarily a purposeful one, a functional hypertrophy. With an undiminished demand for chrometin during functional activity of the cell, the cell body is forced to take in an increased amount of material from the outside, and the nucleus, in turn, makes an increased demand on the cytoplasm. This enlargement of the cell furnishes a valuable index as to the stage of activity of a cell at any given time.

Briefly summarized, there are two factors upon which the anatomical diagnosis of conditions of functional activity is based. They are the shift in amount of chromatin within the cell from hyperchromatism to hypochromatism and on to complete loss of chromatin in exhaustion, and the shift 
in the nucleus-plasma relation. In the hyperchromatic stage, this is necessarily a shift in favor of the nucleus; later, however, the shift is in favor of the cytoplasm and remains so until exhaustion.

The morphology of the process of depression of function is very different from that of functional activity just described (Figures 14-16). Depression of function, as the name implies, is merely a stoppage or inhibition of the physiological function of the nerve cell at any stage of activity. In studying the nerve cell in depression, there are found depressed cells of all stages of activity from the resting cell to the late stages of exhaustion. It is not considered necessary that the anatomical changes of depression be considered in detail for the stages of activity and only the more general effects upon the cell will be noted.

The mioroscopical sppearance of a cell in depression and of the same cell in a certain stage of functional activity is different in that in depression the nucleus is found to contain varying increased amounts of chrometin, corresponding to the degree of depression, while the cytoplasm is deficient in chromatin to a corresponding degree. In the resiting cell, which normally shows an abundance of extranuclear chromatin, this extranuclear deficienoy varies from an appreciable lessoning in amount to an absolute disappearance. The same is also true for the hyperchromatio cells, which normally have an excessive amount of extranuclear chromatin. Sharply defined 
granules gradually become less distinct and the acid staining elements of the cytoplasm become more distinct, until finally there is little or no basic staining substance left. In the intermediate stages, just before the final 10ss of basic staining substance, the stained cytoplasm mey appear murky and look $8 \mathrm{~s}$ if it were poorly stained. The cytoplasm sometimes has a turbulent, floccular appearance or the remaining basi-chromatin may appear as fine dust-like particles.

Depression produces the same changes in the hypochromatic cells as those just described for the hyperohromatic cells. However, these changes are not so obvious due to the normally lessened amount of chromatin in the cytoplasm of the hypochromatic cells. The marked edoma present in the more advanced stages of hypochromatism also changes the appearance of the cytoplasm from a deep acid staining, hyaline mass to a much lighter staining and more reticular mass. The changes in the nuoleus due to depression are 8 well marked as those in the oytoplasm. There is an upset of the nucleus-plasma relation in favor of the nucleus in the early stages. This increase of the intranuclear chromatin in depression is most characteristic, since for the most part the normal nucleus of the nerve cell contains no basic chromatin except in the karyosome. The deposition of the chromatin may be in the form of well defined granules or it may be sometimes found in a more diffuse form, causing the nucleus to appear as a homogeneousbesic staining substance. The 
nucleus may also show accessory karyosomes which are more numerous in the more advanced stages. In the final stages, karyorrhexis, or a disintegration of the karyosome may appear, leaving the true, acid staining nucleolus. At the time of complete depression, the nucleus appears as a homogeneous, formless mass, taking predominantly the basic stain, as opposed to the more granular and acid-staining appearance in the cytoplasm.

Dolley (1913), by special stains and methods, has found that associated with profound depression there apears in the cytoplasm a deposition of yolk material and of glycogen. The yolk material was noted as appearing not only In distinct globules but also in more diffuseform, causing the eytoplasm to appear somewhat opaque as if the tissue were improperly fixed. This deposition of yolk material in depression has also been demonstrated to occur in the sex cells and other body cells. It has a marked significance for it demonstrates the fact thet the cytoplasm is incapacitated for work to such a degree that the raw material taken in is not syrthesized but is deposited in the cytoplasm unchanged. This same significance is also attached to the deposition of glycogen in the cytoplasm. Tests for glycogen absorption in the normal nerve cell have been made with negetive results, though it does occur to excess in depression. It appears that this absorption of glycogen In depression may be due to some chemical change in the oytoplasm. However this has not been shown as jet. 
Depression of function as shown by the changes in the nerve cell then may be briefly summarized as follows:

(A). A lessening in the amount of chromatin in the cytoplasm and an increase in the amount of chromatin within the nucleus, which signifies a shift of the nucleus-plasma relation in favor of the nucleus.

(B). A deposition of yolk material in excessive amounts in the cytoplasm.

(C). A deposition of glycogen.

(D). At its maximum, a breaking up of the chromatin of the nucleus into a homogeneous mass, together with karyorrhexis. The process here becomes a condition of degeneration. 


\section{METHODS OF ANESTHESIA EMPIOYED}

Dogs were used in this series of experiments as they appeared more resistant to the after-effects of anesthesia than guinea pigs and rabbits. Only healthy young animals were used, the most of them being less then three jears old.

Ether was the anesthetic employed and the time length of the anesthesia was varied in the different experiments. Because of the fact that it was deemed necessary to produce anesthesia for considerable periods of time, an apparatus was constructed for its administration which would decrease the liability of producing pneumonia. This apparatus (Text-Figure 1 ,page 14a), is a simple device which, however, was found to be very useful and efficient. It consists simply of an ether bottle (G), with a valve (F) to supply outside air; a bottlo (D) through which the ether vapor from $G$ is passed to be warmed; a metal continer for $D(E)$, in which water at $34^{\circ} \mathrm{C}$ circulates to and from a metal coil (H) surrounding an electric light bulb, the whole imbedded in an asbestos and plaster of Paris cast; and a throat tube (A) running from the warming bottle $D$.

In order to use the apparatus the animal is first anosthetized and the throat tube inserted. This throat tube is made of glass tubing and is so shaped and curved that it may be passed through the mouth and will fit snugly into the trachea. At inspiration outside air is bubbled 
$14 \mathrm{a}$

ETHER TARIING APPAFATUS

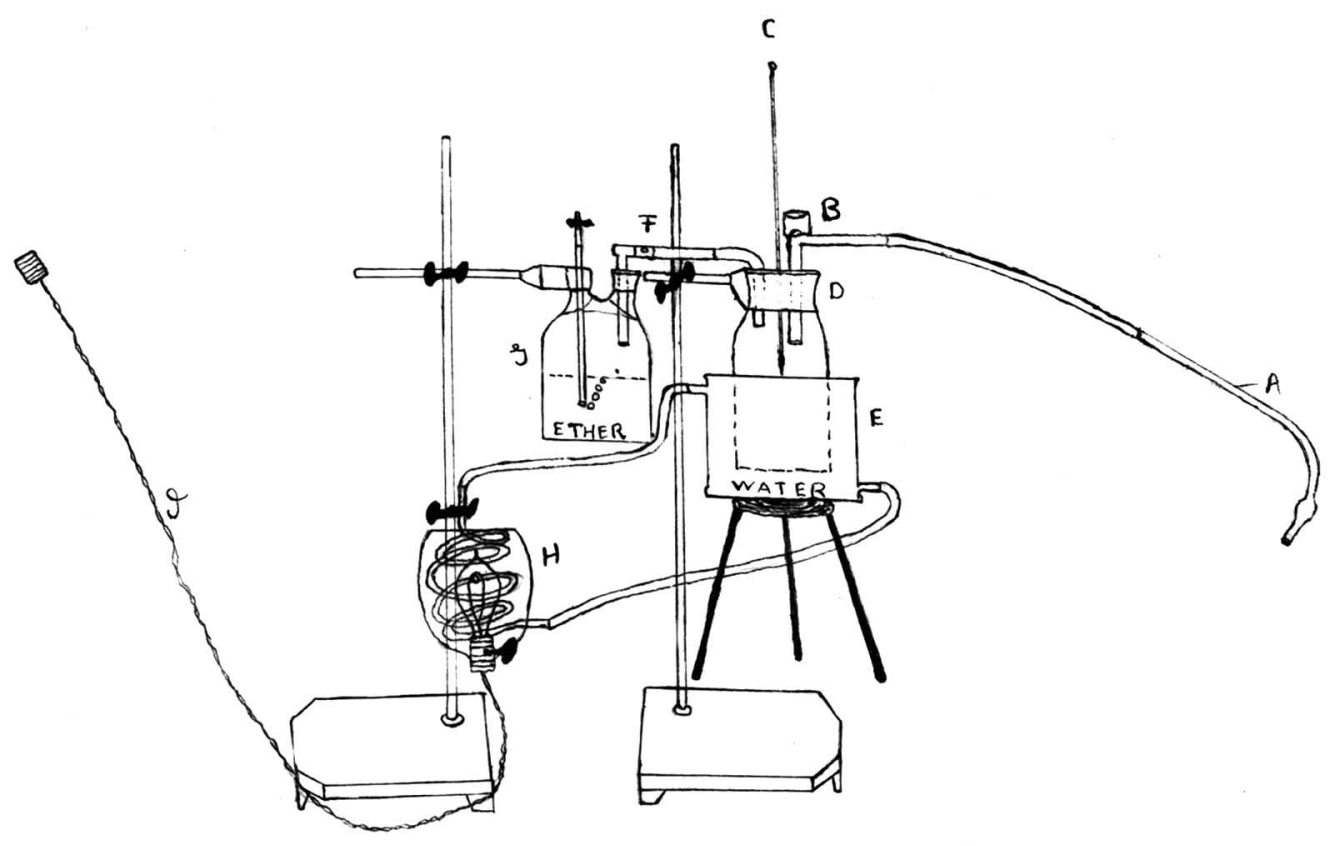

A. Throat tube.

B. Valve to allow the escape of expired ether vapor.

C. Thermometer.

D. Bottle through which ether vapor is passed to be warmed.

E. Metal container in which warm water circulates.

F. Valve to supply pure air.

G. Ether bottle.

H. Asbestos cast containing metal coil surrounding electric light bulb.

I. Electric light connection. 
through the ether in the ether bottle $G$ and into the warming bottle $D$ and to the lungs of the dog. At expiration most of the expired air escapes at valve $B$.

With this apparatus anesthesia can be kept at $a$ uniform degree of depth for considerable periods of time without danger to the animal. It hes quite a number of advantages over the open mask method.

First, it provides warmed ether vapor. In the experiments in which this apparatus was not used microscopical examination of the lung tissue showed well developed and marked pneumonia. In reviewing the literature on anesthetics, only two publications were found which attempted to prove the uselessness of warmed anesthetics, while numerous investigators, Gatch (1910), Coburn (1912). Bojle (1912), and others, have made experiments which prove the value of warmed anesthetics. These investigators report that not only is the "velue of the anesthetic inoreased as regards life but the after-effects are reduced to a minimam."

One of the publications referred to above, "The Fallacy of Warmed Ether Vapor," by Seelig (1911), was objected to by Gwarthmey (1912) in a later paper. He says that Seelig's experiments were evidently imperfect; that ether can be heated easily and inexpensively. The present experiments have shown that there is decidedly a value in warmed anesthetics, especially in ether anesthesia of many hours duration. 
Second, in further enumerating the advantages of the anesthesia apparatus over the open mask method, it is noted that with it anesthesia can be kept at a uniform degree of depth for any desired length of time.

Third, the apparatus requires far less attention of the anesthetist. This fact, although not of a great deal of importance, was of considerable convenience in the present experiments, as the apparatus could be regulated and the anesthetist could then go about other work, sometimes for as long as an hour. It is entirely feasible to keep two sets of apparatus going at the same time as it requires but little more attention to watch the two than one, and in this way quicker results were obtained. Fourth, the apparatus provides a uniformity in all experiments.

Fifth, it requires a less amount of ether. In the review of the literature of anesthesia, it was noted that there were similar yet much more complicated and elaborate forms of apparatus now in use in some of the best hospitals. For animal work, in the writer's experience, this simple apparatus is entirely satisfactory. 


\section{MICROSC OPIC TECHNIC}

Following the experimental work of Mann (1894), Fleming (1895), and V. Ienhoseek (1897), sublimete was constantly used for the fixation of brain tis8ue. This fisetive, which is the adopted one of this laboratory for brain tissue, gives very satisfactory results. It produces no undue distortion of shape of the nerve cells, and, in view of the fact that much depends on this feature in the anatomicel diagnosis of nerve cell activity, it is much superior to the ordinarily used fixetives, particularly etrong alcohol.

However, Dolley (1911), has compared the results obtained from the more commonly used types of fixetives and has noted that no matter what ficative is used the. findings in the nerve cell are constant.

The aqueous sublimate was combined with formalin according to the following proportions.

Saturated corrosive oublimate $40 \%$ formaldehyde

From twelve to twenty-four hours were generally allowed for fixation, and then the tiseue wes run through the graded alcohols up to 80\% alcohol, in which it was lodized for six dajs before it was placed, for one day each, In $95 \%$ and absolute aloohols. From that stage the tissue 
was run through as follows:

Absolute alcohol and solol (equal parts) one hour. Xylol, one to four hours.

Parafin dissolved in xylol (room temperature) 3 to 5 hours.

Paraffin aissolved in $x$ lol (oven temperature) 3 to 5 hours.

Melted paraffin (in oven), six hours.

Imbedding in paraffin.

Sections were cut of five micra thickmess and mounted on thin sides.

The technic used in staining is rery simple. Following the routine of this laboratory, erythrosintoluidin blue was used. The toluidin blue is a saturated aqueous solution. Erythrosin, which 18 omplojed as a counterstain, is that in the solution of Held, 1.0., one gram to one hundred and fifty cublo centimeters of distilled water, to which are added two drops of strong acotio acid.

The staining of the sections was carried out acoording to the following procedure: After the parafein was dissolved from the sections they were pessed through the graded alcohols to water. They were then etained one and one-half minutes in erythrosin solution heated to 40 degrees C. 
After thoroughly washing in water, they were stained in toluidin-blue solution for about seven minutes, again washed in water, and then differentiated by passing through $80 \%$ and $95 \%$ alcohols. The process of differentiation was followed under the low power of the microscope and stopped when the internal markings of the celle became clear. After the sections were placed in absolute alcohol for a few minutes they were cleared in xylol and mounted in Canada balsam.

In looking over this microseopic technio, the noticeable fact is that only the ordinary oytological methods were employed and that no unusual stains were neoded. 


\section{DATA OF EXPERIMENTS}

Experiment Anesthetic 2. (numbered in laboratory series). Large male dog, probably two or three years of age. Weight about $12 \mathrm{Kg}$. Anesthesia by the open mask method. Time length of the anesthesia $13 \mathrm{hrs}$. and $40 \mathrm{~min}$.

Remarks:-- The animal was hard to keep anesthetized, requiring a considerable amount of ether. A noticeable fact was that after about 8 hours more ether was required to keep deep anesthesia, as judged by the absence of eye reflexes, than was needed during the previous 5 hours. For several hours previous to the time of death of the dog ether was almost continuously poured down the mask without any apparent change in the depth of the anesthesia and an eje reflex was present from then until the time of death.

Post-mortem findinge:-- Marked hypostatic congestion of the lungs. On mioroscopical examination, a marked pneumonia was noted.

Fxperiment Anesthetic 3. Apparently an old male dog. Weight $6 \mathrm{Kg}$. Anesthesia with the ether warming apparatus. Time length of the anesthesia for the first day, 6 hours; for the second day, 6 hours. Total time of anesthesia 12 hours.

Remarks:-- This animal was easily kept anesthetized and required only a small amount of ether to keep deep anesthesia. 
Post-mortem findinge were negative as far as influencing any factor of this experiment was concerned. Tubercles were found throughout one lobe of the left lung.

Experiment Anesthetic 4. A medium sized female dog, three years of age. Weight $8 \mathrm{Kg}$. Kept under deep anesthesia 3 hours the first day, 4 hours the second day, and 6 hours the third day, at which time it was killed. It was noted during the 4 hours previous to its death that even in very deep anesthesia an eje reflex was present. There were negative post-mortem findings.

Experiment Anesthetic 5. A three-fourths grown female dog. Weight $8 \mathrm{Kg}$. Time of anesthesia, 2 hours. Remarks:-- The animal was very easily kept under the anesthetic, requiring only a very small amount of ether in comparison with the other dogs in Experiments 2 and 4. At no time during the anesthesia was an eye reflex present except for a minute or two at a time. A post-mortem showed nothing abnormal.

Fxperiment Anesthetic 6. A four-fifths grown femele dog. Weight $8 \mathrm{Kg}$. Time of anesthesia 4 hours. The animal was difficult to keep anesthetized.

Fxperiment Anesthetic 7. A four-fifths grow female dog. Weight $7 \mathrm{Kg}$. Time of anesthesia 6 hours. The dog was hard to keep under the anesthetic.

Experiment Anesthetio 8. A small bull dog of less than two years 0ld. Weight $6 \mathrm{Kg}$. Time of anesthesia 5 hours. 
Experiment Anesthetic 9. A female dog of less than three jears old. Time length of anesthesia the first day, 3 hours, the second day 1 hour.

Experiment Anesthetic 10. A female dog of apparently about 2 or 3 years old. Weight $10 \mathrm{Kg}$. Time of anesthesia 8 hours. Heart rate 170 per minute, respiratory rate 102 per minute at the time the anesthetic was removed. After one-half hour the respiratory rate had become very rapid, 280 per minute. Heart rate could not be ascertained. At two hours after the anesthetic was removed the respiration and heart rate had returned almost to normal, but the animal could not even raise its head so great was the collapse. The following morning the dog was found dead, 15 hours after the anesthetic was stopped.

Post-mortem findings negative.

Experiment Anesthetic 11. A female dog of good vitality and apparently less than one year old. Weight $6 \mathrm{Kg}$. Time of anesthesia the first day was 4 hours. On the second day, the animel was apparently recovered and sbowod no effects of the previous day's anesthesia. On the third day the time of the anesthesia was 7 hours. Onehalf hour after the removal of the anesthetic there was noted a very shallow, fast respiration, a heart rate of 260 per minute, and the animal romited repeetedly. At one hour later the respiratory rate had decreased but was still 146 per minute. The dog had cutaneous reflexes, but otherwise 
was apparently lifeless. It could not raise its head. Four hours later the dog had recovered to a slight extent and could raise its head. Fifteen hours later, the heart rate was 170 and the respiratory rate was 56. The dog howled at times and would try to move but merely went around in a circle, as if partially paralyzed. It was very excitable as it would try to move whenever a noise, such as clapping the hands, was made in the room. Thirty houra later there was no noticeable change from what has been desoribed. At forty hours after the anesthetic was stopped the dog was found dead.

Post-mortem findings:--abdominal organs congested with blood. An intussusception was found in the small intestine. Experiment Anesthetic 12. A femele dog of about two years old. Weight $8 \mathrm{Kg}$. Time of anesthesia 8 hours. Ten minutes after removal of the anesthetic the respiratory rate was 216 per minute. The heart rate could not be ascertained. One half hour later the respiratory rate had increasad to 330 per min. Two hours later the respiratory and heart rates had returned almost to normal but the animal appeared almost lifeless. Four hours after the removal of the anesthetic the dog was found dead. Post-mortem findings were negative. 


\section{DESCRIPTION OF THE CHANGES}

PRODUCED BY ETHER AND THEIR CORREIATION WITH DEPRESSION

Before a thorough microscopical examination and study of the material obtained in this series of experiments was begun, a careful study was made of the Purkinje colls of the cerebella of normal dogs, and of dogs in a state of profound depression which had been produced by a known depressant. This was done in order to become familiar with the microscopical appearance of these cells in the various stages of normal functional activity and in the varlous grades of depression.

On making the microscopical examination of the cerebellar tisgue in the first of this series of experiments, Experiment Anesthetic 2, it was noted for the first time that ether anesthesia produces depression of the nerve cells. The changes of depression which had been produced by the thirteen hours and forty minutes of anesthesia were very marked, in fact, all of the Purkinje celle showed some dogree of depression. The essential changes were also noted to be similar to those produced by the known depressents. There was a loss of basic-staining substance in the protoplasm causing it to have a murky appearance. some of the colls showed varying amounts of chromatin in the nucleus in the form of well defined granules, while in some the nucleus appeared as a formless, homogeneous, basic-staining mass. The karyosome showed in some of the cells complete 
karyorrhexis, in others only the beginning of disintegration. Depression was again noted in the next two experiments, Anesthetics 3 and 4 . In these experiments anesthesia of several hours duration daily for several successive days was shown to produce an almost as marked degree of depressIon in the nerve cells as a continuous anesthesia for the same number of hours. For example, an anesthesia of 4 hours daily for three successive days produced almost the same degree of depression as a continuous one for 12 hours. Having found that ether anesthesia produces the changes of depression, it was decided to ascertain, if possible, the shortest time in which these changes would appear. For this reason experiments $5,6,7,8$, and 9 were performed. As a matter of convenience to the reader the lengths of anesthesia of these experiments will agein be stated. They are as follows: Anesthetic 5, 2 hours; Anesthetic 6, 4 hours; Anesthetic 7, 6 hours; Anesthetic 8, 5 hours; Anesthetic 9, 4 hours.

In each of these experiments depression of the nerve cells was noted in the material examined. However, there was only a mila degree of depression in the four experiments, $5,6,7$, and 8 . The depression involved only a portion of the cells, the most of them showing no apparent change. The cells involved showed a diminution or an abence of extranuclear chromatin in the protoplasm, the protoplasm having a diffuse basic-staining appearance. There was very little change in the nuclei and karyosomer. 
Apparently the depression had just made its appearance.

It was further noted that there was very slight difference in the degree of depression in these four experiments although the time lengths of the anesthesia varied. A noticeable fact was that the dog which was easily kept anesthetized showed almost as marked depression after two hours anesthesia as the dogs which were herd to keep anesthetized but which were kept in that condition 4,5 and 6 hours. It was the observation in these four experiments, as well as in the others, that the animals which were easy to keep anesthetized showed the changes of depression earlier than the animals which were hard to keop anesthotized. In three of these experiments, 5, 6, and 7 , there was also a uniformity, as far as possible; the dogs were practically the same age and weight, and the ether warming apparatus was used.

It appears from this that the changes of depression produced by ether anesthesia vary with the animal as well as with the time length of the anesthesia, and that these changes first appear microscopically after about one and onehalf to two hours, through they may be delayed several hours Ionger. In the previous study of nerve cells of animals kept under ether anesthesia for less then one and one-half hours during numerous operations, no depression had been noted (Dolley 1914).

In Experiment 9, an enesthesie of three hours on the first day and one hour on the second aly, there was noted 
a higher degree of activity than normally found and only a few of the cells showed depression. This would then indicate that there are produced by the ether anesthesia first the changes of excitation on which are superimposed the changes of depression. It may be interpreted from the description of Cavalie and Rolland (1903) that anesthesia primarily stimulates the cells to activity.

In the last three experiments, 10, 11 and 12, a most marked and profound depression was found on making the microscopical examination of the material. This marked depression was seen in practically all of the cells. Not only did they show marked depression but large numbers of them showed degeneration and beginning necrosis. Especially was this noted in cells of Experiment 12 , in which the animal lived forty hours after the anesthetic was stopped. In each of these three experiments a symptomatic condition, which at first wes very aifficult to properly diagnose, accompanied these changes in structure. This condition, which will be discussed in detail in the next chapter, is regarded as probably the outward constitutional effect of profound depression. It made its appearance only in the experiments in which practically all of the nerve cells showod marked depression and in which large numbers had begun to degenerate and appeared incapable of function.

To summarize briefly: Depression was noted in all of the experiments performed. The degree of depression produced was in proportion to the time of anesthesia, with allowance for the individual variations of animals. An 
anesthesia of two to six hours produces a moderate depression, one up to eight hours a marked depression, and one of more than eight hours a profound depression, with the beginning of necrobiosis. 


\section{DISCUSSION OF CERTAIN \\ CONSTITUTIONAL EFFECTS OF THE ANESTHETICS}

The symptoms of the constitutional effect referred to in the last section will now be discussed. It was the observation in Experiment Anesthetic 2 that after about eight hours anesthesia a larger amount of ether was borne indifferently by the animal. At least this appeared to be the case, for it seemed to make very little difference how much ether was given as the eje reflex remained present and the respiration was shallow until the death of the animal. This was also the observation in Experiments 3 and 4, beginning each time after eight to ten hours anesthesia. However, very little attention was paid to this condition until several recovery experiments were performed. In these, Experiments 10, 11 and I2, anesthesias of approximately eight hours each, it was decided instead of continuing the anesthesia until the death of the animal, as in the other experiments, to stop after it was thought depression had been produced in order to study recovery changes. The condition described as appearing after eight to ten hours in Experiments 2,3 and 4 had also begun in the recovery Experiments 10, 11 and 12 before the removal of the ether. In the latter experiments, however, not ended by intentionally killing the dogs, the condition developed to its full extent. 
It was too serious to permit recovery, as all the dogs died within two days, but for itself it was a fortunate turn which permitted its study.

This condition, which appeared to be the outward symptomatic effect of depression, was as follows: on the removal of the anesthetic the already rapid and shallow respiration of the animal gradually increased until it became a violent pant, in one case becoming as rapid as 330 per minute at half an hour after the removal of the ether. This respiratory rate could be counted only with difficulty and was estimated at 330 per minute by repeated counts. The heart rate could not be ascertained bocause of the marked respiration. At one hour after the removal of the anesthetic the respiratory and heart rates were back to normal and the dog had reflexes but lay upon the floor more or less unconscious, with a lowering of temperature and probably blood pressure, and partial paralysis. It appeared to be in a condition of very marked collapse. The animals remained in this condition until death, in one case 40 hours after the removal of the anesthetic, never recovering muscular control.

In the review of the Iiterature on anesthesia there were found several reports of the occurrence of a similar condition. These investigators have explained it as a post-anesthetic intoxication (Brown, 1911 and Inman,1911) or as a delayed post-anasthetio poinoning associated with 
sepsis (Rees,1912). Turck (1903) calls the condition shock. He produced this"shock" with ether anesthesia - as he says in the absence of trauma, hemorrhage, fright, or manipulation of the visceral organs. He also says that shock is intimately associated with the nervous system. The description of the animals in the condition he terms shock was exactly the same as thet noticed in the animals of these three experiments. He noted also that some animals would show the evidences of this condition more readily than others of the same species. This fact bears out what was noted in these experiments, namely, that the degree of depression varies with different doge. White (1899) echoes the universal clinical observation that anesthesia always adds to shock. Hewett (1857) claims thet surgicel shock will occur more readily under ether than chloroform.

This condition of collapse just described appeared to be the outward physiological symptomatic effect of a profound depression. While it is not possible at present to explain each individual symptom on the basis of cjtology--that being a question of physiological relations-a fundamental understending of the origin of the condition as a whole is afforded. As stated, the symptoms appeared only in the experiments in which practically all of the nerve cells exemined showed marked depression, and in which large numbers had begun to degenerate. In other words, 
their capacity for function was minimal, and the physiological reaction must be connected with this changed anatomical structure. neither

The condition was not one of shock, as Turck names it, according to the usual restriction of the term, nor as cytologically interpreted. As more commonly used, shock is surgical or traumatic. Mechanical stimulation is the physiological factor, and this traumatic stimulation excites the nerve cells affected to activity, then fatigue results and finally exhaustion. All symptoms are referable to the results of stimulation (Dolley 1910). In a more general sense the principle can be extended to any form of stimulation such as the shock of pain or emotional disturbance. There is no positive evidence that mechanical stimulation ever produces depression, though there is much negative evidence (Verworn, 1899). The ether collapse then is not shock. As to its origin it is the exact opposite of shock. Instead of overfunction, there is. inhibition of function of the nerve cells.

Depression explains entirely the most marked and characteristic symptom, the partial paralysis of the animals. This corresponds with the results of simmons from this laboratory (1914). He noted that the paralysis after diphtheria toxin was coincident in time with marked depression in which there was degeneration and beginning necrosis of the Purkinje cells. 


\author{
Depression also explains by itself the fall in \\ temperature and in blood pressure. It does not alone, \\ however, explain the over-activity of the heart and \\ respiratory mechanisms. It can be suggested that de- \\ pression removes the inhibition of the higher centers, so \\ that these organs are no longer under the usual re- \\ straint. The very rapid respiratory rate and heart \\ rate had stopped many hours before the death of the \\ animals. \\ It is also clear why Turck diagnosed the condition \\ as shock. The ond of shock is organic exhaustion. Com- \\ plete exhaustion must be accompanied by loss of function. \\ Depression is primarily a loss of function. From opposite \\ causes the same functional incapacity is reached (Dolley \\ 1914). In its extreme, therefore, complete ether do- \\ pression must give many symptoms in common with shock \\ exhaustion.
}




\section{REVIEW OF THE IITERATURE}

In a review of the literature since 1895 it was strikingly demonstrated that very little investigation has been made on the nerve cell and especially on the effects of anesthetics on the nerve cell. In fact, after carefully searching the literature as reported in the Index Medicus, only six publications were found in which the effect of the anesthetics on the nerve cell has been studied. There were however, to be found numerous publications on the effect of various anesthetics on the nerve fiber but these were of no value on this investigation.

The investigators, a review of whose publications will be stated later, have given different interpretations or no interpretations at all of the various changes in the nerve cell which they considered to be produced by anesthesia. However, none of these investigators regarded their findings from the point of view of this paper, that is, of a functional analysis.

Such interpretations as are given incline to the idea of toxemia or degeneration, rather than to a natural process of stimulation in its broad sense. Consequently, only their objective findings will be examined in this review in respect to agreement or possible disagreement with the present results. Changs which are now known to belong only to normal function are usually considered to be artefacts 
or degenerations.

Cavalie and Rolland (1903) studied the action of a mixture of ethyl chloride, ethyl bromide, and methyl chloride on the Purkinje cells of the cerebellum of the cat, guinea pig, and rabbit. Their methods were as follows: Anesthesia of five minutes, anesthesia of fifteen or twenty minutes, anesthesia of one hour or more, and anesthesia of one hour followed by one hour of rest. The results briefly summarized were: After five to ten minutes of anesthesia there was no apparent change in the pyramidal colls or Purkinge cells, although there were changes in the axones which, however, are of no interest in this investigation, and for this reason will not be stated. After one hour or more of anesthesia, the modified structure of both Purkinje and pyramidal cells was fairly well marked, and "the nuclei which were more or less visible were colored about the same as the protoplasm." These results are interpretated by the writer as oimply the changes due to primary excitation. Their conclusions briefly stated are: That the effect of a general anesthetic ought to be considered as that of a substance more or less toxic: that a general anesthetic produces a certain number of important changes in the Purkinje and pyramIdal cells; that at the beginning of anesthesia the Purkinje cells are stimulated while the pyramidal oello remain intact; that there is sort of an elective affinity of the anesthesia for cellular elements of Purkinje colls, and that anesthesia 
acte first by its affinity on the cerebellum and next on the cerebum; that with chloroform anesthesia for periods of one-half to one and one-half hours there was no apparent change microscopically in the pyramidal cells of the cerebrum or the Purkinje cells of the cerebellum.

Tedeschi (1897) studied the acute poisoning of chloroform and noted that there was an abating of the swelling of the protoplasm with diffusion of the chromatic substance of the nerve cell.

Feischi (1898) noted that besides the diffuse coloring of the protoplasm of the nerve cells of the anterior grey horn there existed between the cells a diversity of coloring.

Schmidt (1898), with repeated anesthesia, observed in the nerve cells: of the ganglia of the heart fragmentation, disappearance, and lumping of the chromatin, enlargement of the cell and vacuolation of the protoplasm.

Camia observed with acute poisoning a thinning and diffusing of the lumped chromatin in the protoplasm of the cells of the grey substance in the cortex of the pons, bulb, and medulla.

It appears that Schmidt and Camia very probably produced the changes of depression although they did not interpret them as such.

Wright (1900) studied the action of ether and chloroform on the neurons of rabbits and dogs. Some of his conclusions, 
which are of value in this investigation, are as follows: "In rabbits both ether and chloroform anesthesia cause certain changes in the nerve cells of both brain and spinal cord. These are slight at first, but become more pronounced as the anesthesia is continued. By the methylene blue method, the principal change is rarefaction (or lessening) in amount of the Nissl bodies, in the most marked cases of all, a pseudo-degenerative change." The rarefaction must refer chiefly to the hypochromatism of activity and from the plates which he presented, the Hodge stage of activity is included in his pseudo-degenerative change. He also noted that in dogs there are practically no changes up to two hours, but that between that time and four hours changes occur in the nerve cells similar in kind to those observed in the rabbit. The changes become more marked as the anesthesia is continued.

From this summary of the Iiterature it appears that the anesthetics produce certain changes in the nerve cells. The changes after anesthesias of short duration appear to be only the chenges of excitation while those of longer or repeated anesthesia can be identified as depression. The investigators noted that there were no marked changes produced by anesthesia up to one and one-half hours but that they made their appearance between that time and four hours, and that the changes produced depended upon the auration of the anesthesia. These two statements both agree with the results obtained in this investigation. 


\section{SUMMARY}

Bther anesthesia produces certain definite anatomical changes in nerve cells of dogs. The changes are first those of mild activity and later there are superimposed changes of depression depending in severity upon the duration of the anesthesia. The changes first make their appearance microscopically in one and one-helf to two hours. An anesthesia of two to six hours produces a moderate aepression, one up to eight hours a marked depression, and one of more than eight hours a profound depression, with the beginning of necrobiosis.

The severity of the anatomical changes in the nerve cell appears to be in direct relation to the length of the anesthesia, allowance being made for individual variations.

The changes vary in degree in animals of the same species kept under the same form of anesthesia for the same length of time.

An anesthesia of several hours duration for several successive days produces almost the same degree of depression in the nerve cells as a continuous one of the same number of hours.

Animals which are easily kept anesthetized show more marked anatomical changes in the nerve cells than animals that are kept under the anesthesia with difficulty when the time length and the kind of anesthesia are the same. 
A peculiar constitutional condition of collapse results from anesthesia of eight or more hours duration. This condition of collapse is coincident with profound depression, and the depression is considered to stand in causal relation to this condition. 


\section{BIBLIOGRAPHY}

Azoulay. I895 Psychologie histologigue et texture du systeme nerveux. Annee physiologigue. I895.

Boyle,Edmund. I9I2 Intratracheal insufflation of ether. Brit. Med. Jour. I9I3. No.I.

Brown, G. I9II Two cases of death from post-anesthetic acid intoxication. Brit.Med. Jour. I9I2. No.2. xi.

Cavalie, M. et Rolland, M.G. I904 Influence d'un anesthesique (le somnoform) sur les centres nerveux; (son successive action our le cervelet et our le cervean). Cong. de med. I904. xiv. Sect. d'anat.

Cotton, F.J. I9I2 The uselessness of warming anesthetic vapors. Surg. Gyneo. \& Obst. I9I2. XV.

Cavalie,M. et Rolland, M.G. I903 Recherches sur l'action du chloroforme sur le system nerveux central. (Cervelet et cerveau). Odontologie, $x i x$.

Coburn,R.C. I9I2 A new apparatus for administering and warming general anesthetios and new methods of administration. Jour. Amer. Med. Ass. I9I2. IVil.

Dolley, D.H. I909a The pathological oytology of surgical shock, I. Jour. Med. Research. $\mathbf{x x}$.

I9I0 The pathological cytology of surgical shock, II. Jour. Med.Research. xail.

I9II The recuperation of nerve cells. Jour. Med. Research. xxiv.

Simmons, R.R. Thesis. Univ. of Mo. I9I4. The physiological significance of the anstomical changes produced in the nerve cells by the action of certain becterial toxins. 
I9I2 The morphology of functional activitity in the ganglion cells of the crayfish, Cambarus virilis. Arch. f. Zellforsch., ix.

I9I3 The morphology of functional depression. Jour. Med. Research. xxiv.

Feischi I898 Alterazione degli elementi nervosi per inalazione di cloroformio. Bolletino della socienta medico-chirugica di Pavia.

Flemming, I895 Arch. f. Mik. Anat. xlvi, 379. Gentile, E. I909 Sulle alterazione delle cellule nei ganglii del sistema nerrosa simpatica, in sequito ad inalazione di oloroformio. Ann. d. Clin. d. mal. ment. 1. nerv. d.r. Univ, di Palermo. I909, iil.

Gwarthmey, J.T. I9I2 The value of warmed anesthetics. N.Y. Med. Jour. Xov.

Gatch, W.D. I9IO Nitrous-oxid-oxygen anesthesia by the method of re-breathing, with especial reference to the prevention of surgical shock. Jour. Amer. Med. Ass. I9IO. IIV.

Guerrin, G. I899 De l'action de la fatigue sur la structure des cellules nerveuses de l'ecore. Arch. Ital. de biol. xxorvil.

Goldschmidt, R. I904 Der Chromidialapparat lebhaft functionierender Gewebszellen. Z0ol. Jahrb.(Anat.),xxi. Holmgren, E. I900 studien in der fieneren anatomie der nervenzellen. Anat. Hefti.,xv.

Hodge, C.F. I892 A microscopical study of the changes due to functional activity in the nerve cells. Jour. Morp., vii. 
Hertwig, R. I889 Úber die conjugation der Infusorien. Abhandl, d. Kgl. Bayer. Akad,d. Wissensch,II. KI.xvii. I903a Über das Wechselverhältniss von Kern und Protoplasma. Sitz.-ber.d.Gos.f. Morph. u. Phys.,xviil.

I903b Über Korrelation von Zell- und Kerngrösse und ihre Bedeutung für die geschlechtlich Differenzierung und die Tielung der zelle. Biol, Centralbl.,xxiii,49-62. I08-II9.

Inman,F.W. I9I2 Post anaesthetic acid intoxication. Brit. Med.Jour. I9II. No.I.

Lenhossek,V. I897 Arch, für. Psychiat.,xxix. Iugaro, E. I895 Sur les modificationes des cellules nerveuses dans les aivers etats fonctionnels. Arch. Ital. de biol, xxiv.

I898 Sulle modificazioni morfologischa funzionali dei dendriti della cellula nervosa. (Hist.Auot.I898). I896 Nuovi dati e nuovi problemi nella patologia della cellula nervosa. Revista di patologia nervosa e mentale. Vol. I. I896. Cong, de med. Mann, G. I895 Histological changes induced in sym-. pathetic, motor, and sensory nerve cells by functional activity. Jour. Anat, and Phys,, Lond. xxix.

Marinesco. I897 Histologie pathologique de la cellule nerveuse. (Congres de Moscou, I897).

Mann, G. I894 Ztschr. f. Wissesch. Mikr, ,xlvi. Rees, W.A. I9I2 Delayed ohloroform poisoning associated with sepsis. Brit. Med. Jour. xi.

Seelig, M. G. I9II The fallacy of warmed ether vapor. Interstate Med, Jour. St.Iöris, xvili. 
Schmidt 1898 Ửer die Verănderungen der Herzganglien bei durch chloroformnarkose. Zeitschrift. f. Biol. Bd. xxxvif. Turck, F.B. I903 Shock produced by general anaesthesia. Jour. Amer. Med. Ass. N. 40.

Tedeschi. I897 Recherche anatomiche e experimentali sugli effeti del cloroformio. Clinica moderna. Thomas, I.K. I905 The corneal reflex in anaesthesia. Brit. Med. Jour. I905. V. II.

Vas, F. I892 Studien über den Bau des Chromatin in der Sympathischen Ganglionzelle, Arch, f. Mikr. Anat.,xi. Verworn, M. I896 Erregung und Iähmung. Verhandle.d. Ges. deutsch. Naturf.u.Ärzte zu Frankfort a M. I. Theil., Ixxiii, Deutsch. Med. Woch, ,xxii.

I899 General Physiology. Translation, the Mac Millan Co. Wright, Hamilton. I90I The action of ether and chloroform on the cerebral and spinal neurons of dogs. Jour. of Phys. 


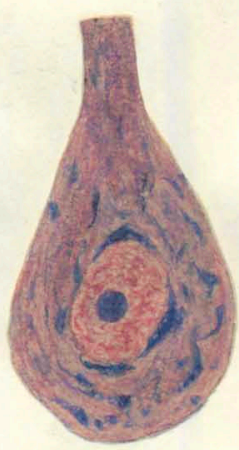

I

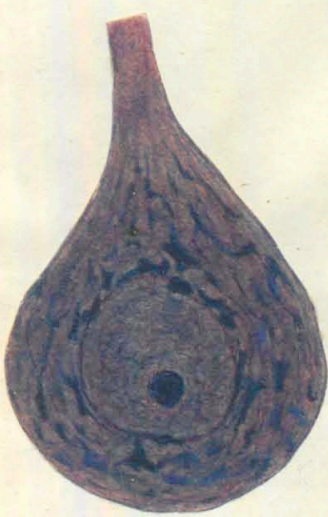

2

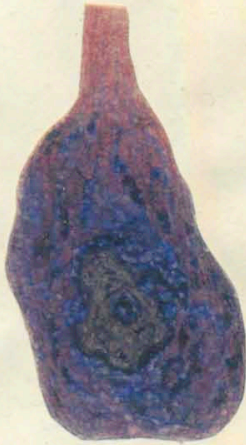

3

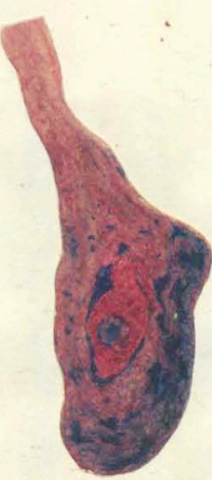

4

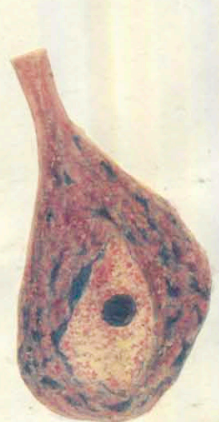

$5^{\prime \prime}$

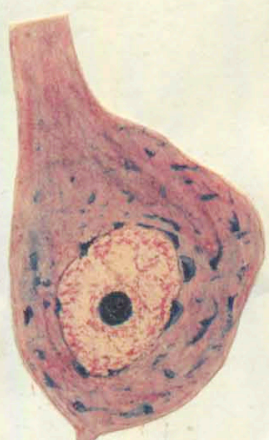

6

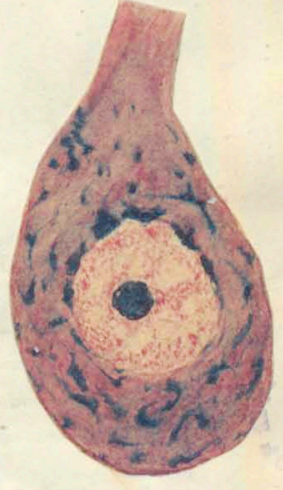

7

Butler 1915. 
STAGES 8 to I3 OF FUNCTIONAL ACTIVITY

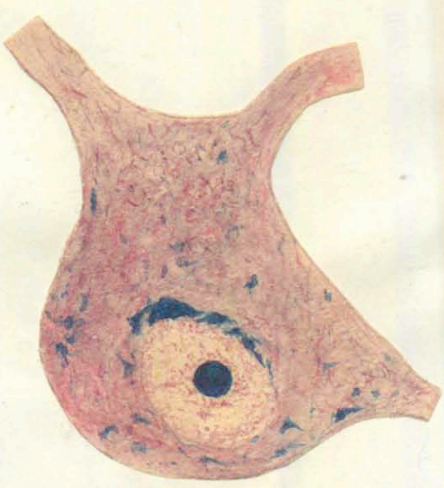

8

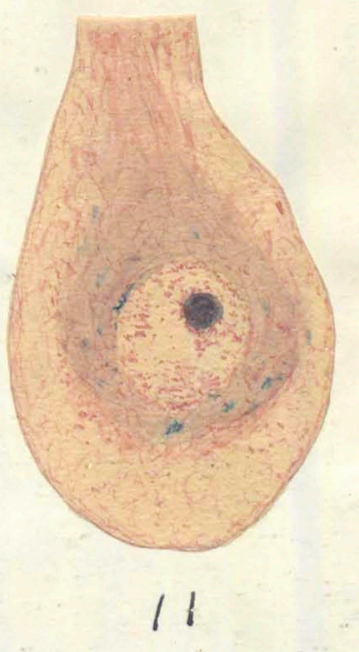

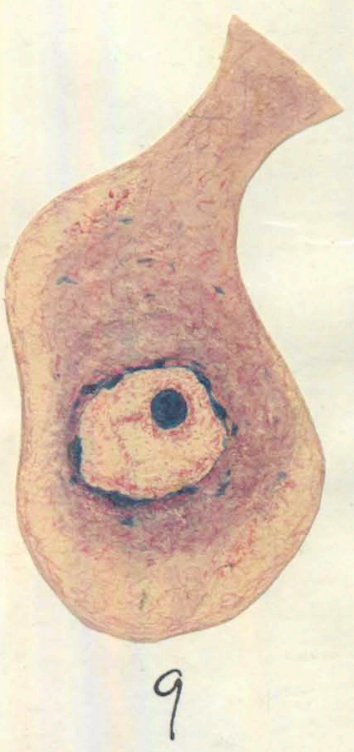
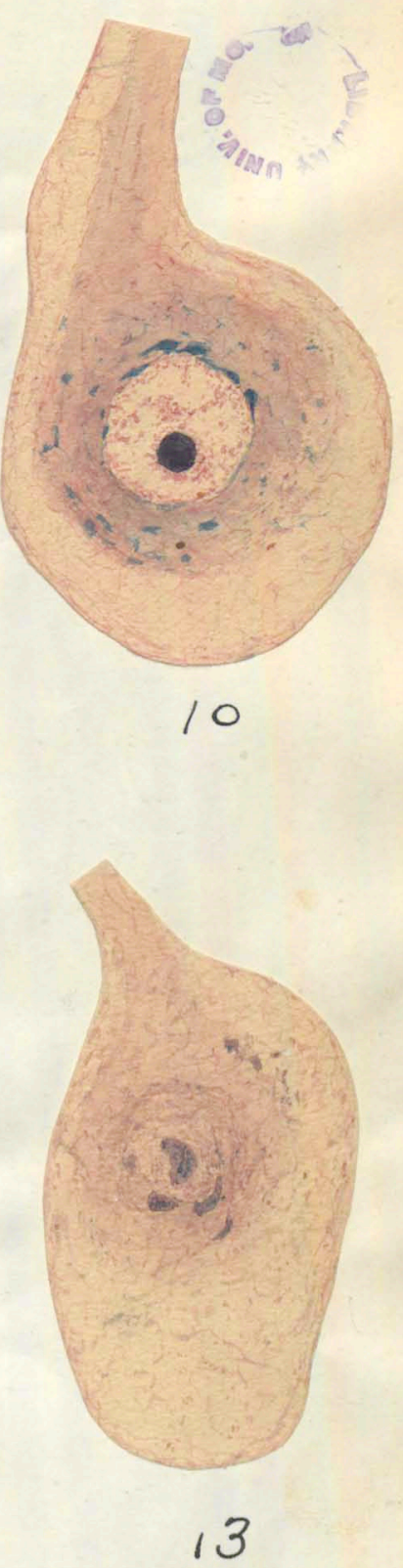

Butler 1915 


\section{DEPRESSION OF FUNCTIONAI ACTIVITY}

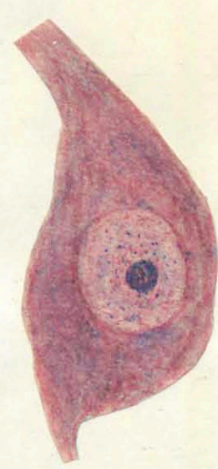

$$
14
$$

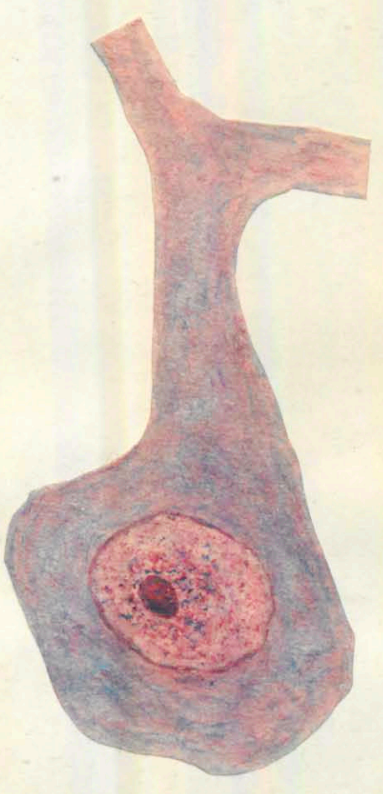

15

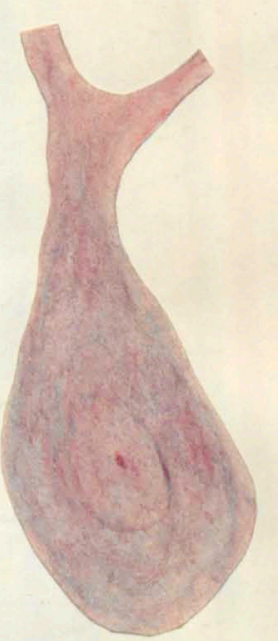

16

Outler 1915

Figure I4. Stage 6 of functional activity in moderate depression.

Figure I5. Stage 8 of functional activity in marked depression.

Figure I6. Very marked depression with early necrobiosis. 


$$
\text { Ma.y 15, } 1915 .
$$

Professor Z. R. Clark,

39 Medical BIdg.

My cear Professor Clark:

It is customary for the Graduate Committee to refer dissertations, submitted by candidates for the degree of Master of Arts, to some member of the Group who is not connected with the Department in which the candidate's work has been done. I am sending you herewith a dissertation" which has been submitted by E. E. Butler. I shall be greatly obliged if you will kindly examine the same at your earliest convenience and report to us for the Graduate Committee whether in your opinion the dissertation meets the general standard which has been established in this University for the Master's dissertation.

Very truly yours,

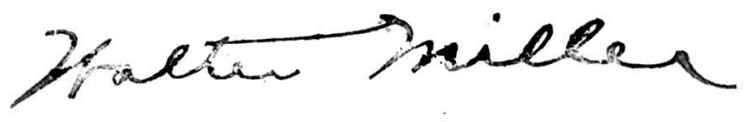

Chairman, Graduate Committee. 


\section{UNIVERSITY OF MisSOURI \\ Columbia}

Dean Walter Milier,

Academic Hall,

Dear Sir,--

I beg to approve the thesis on "An Anatomical

Analysis of the Effects of Ether Anesthesia on the Nerve

Cell," which is submitted by Mr. E. E. Butler from the

Department of Pathology.

Very truly yours,

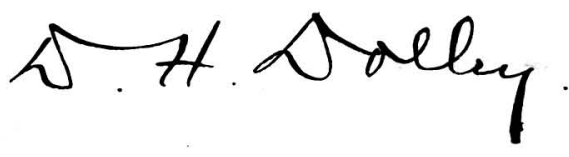


UNIVERSITY OF MISSOURI

Columba

DEPARTMENT OF ANATOMY

if. Walter Wilh,

$$
\text { Way } 22,1915
$$

hcurman, Praduate Commitu,

Acadmic Hall,

My dear Prof. Huiler,-

9 havr rad the descertation

shuitted by thr. E. E. Buther from the Separtiurat Pathology, sutithd "On Anatomeal Analysis the Effects of sotur Austhicia on th Kerva Cell". ar of the filfilment of requinments for the degres Waster of Asts. Asttie is the firet of snch isentations I have sen, I an wuable to is an spinion as fo its value as compand enth here. I can, hoviver, say thal if other thees reuted for the degrer of. U. Q. are as Excellut 
UNIVERSITY OF MISSOURI Columbla

DEPARTMENT OF ANATOMY

is thir, the staidard setableshd in thir Univisity orthie degrer is a vory high one.

Very tuly yours, Eliat P. Clatk. 


\section{$378.7 \mathrm{M} 71$ $X \beta 976$}
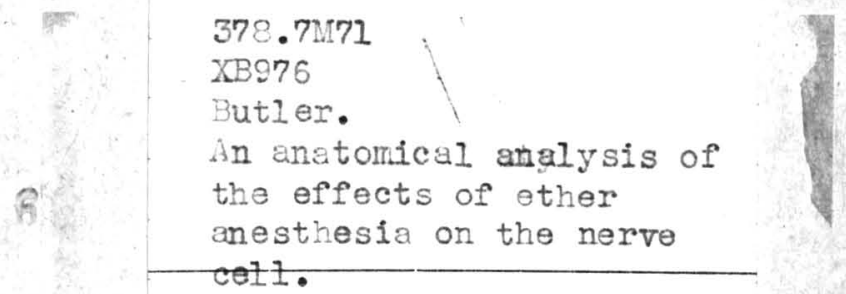

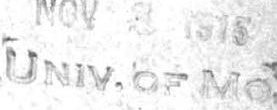


